\title{
Peran Paguyuban Semut Ireng dalam Membentuk Karakter Pemuda Desa Satriyan RT 03 RW 01 Kanigoro
}

\author{
Wiji Lestari \\ Universitas Islam Balitar \\ Email: wijilestariwiwid@gmail.com
}

Anam Miftakhul Huda

Universitas Islam Balitar

Email: a6.asix6@yahoo.co.id

\begin{abstract}
ABSTRAK
Penelitian ini membahas tentang dinamika perilaku anggota paguyuban semut ireng untuk membentuk karakter pemuda dan pemudi desa Satriyan kecamatan Kanigoro kabupaten Blitar. Penelitian ini menggunakan metode deskriptif kualitatif. Teknik pengumpulan data menggunakan 4 teknik, yaitu observasi, wawancara, dokumentasi dan analisis data. Proses analisis data dalam penelitian ini, yaitu pengumpulan data, reduksi data, penyajian data, dan penarik kesimpulan. Hasil penelitian dilapangan menunjukan bahwa peran paguyuban semut ireng dalam membentuk karakter pemuda desa Satriyan Kanigoro dengan cara mengadakan berbagai kegiatan dan memberikan motivasi motivasi terhadap masyarakat desa setempat khususnya pemuda. Agar terbentuknya jiwa sosial disetiap para pemuda. Kegiatan kegiatan yang diselenggarakan tidak hanya yang mengandung nilai sosial saja, melainkan mengandung unsur ekonomi juga. Anggota paguyuban semut ireng berfikir bahwa untuk mengadakan kegiatan kegiatan untuk masyarakat membutuhkan dana yang relativ besar. Paguyuban ini memiliki prinsip logika membutuhkan logistik, maka dari itu sering diadakannya acara makan bersama dengan anggota paguyuban semut ireng. Untuk menjadi anggota paguyuban ini tidak memerlukan syarat - syarat tertentu yang menyulitkan. Melainkan hanya dengan cara ikut serta dalam segala kegiatan dengan menjalani ketentuan yang telah dibuat dalam paguyuban semut ireng. Organisasi ini selain membentuk karakter amnggotanya yaitu pemuda, juga memberikan dampak positif untuk seluruh masyarakat desa Satriyan khususnya di RT 03 RW 01, karena dengan adanya kegiatan yang dilakukan organisasi paguyuban semut ireng menjadi lebih maju dibanding sebelumnya.
\end{abstract}

Kata kunci: pembentukan karakter pemuda

JURNAL TRANSLITERA EDISI 5/2017 


\section{ABSTRACT}

This study discusses the dynamics of the behavior of Paguyuban community Semut Ireng to from the character of young men and women in the village of Satriyan Kanigoro blitar district. This research uses descriptive qualitative methods. Technick of data collection using 4 techniques, namely observation, interview documentation, and analysis data. The process of data analysis in this research is data colletion, data reduction, data presentation, and conclusion. The result of field research shows that the role of the paguyuban Semut Ireng in forming the character of the youth of Satriyan Kanigoro village by holding various activities and motivation's to the local villagers especially youth. So that from of social soul in every youth. The activities held not only contain social values only, but it contains an economic element as well. Members of the community of semut ireng think that to hold activities for the community requires relatively large funds. Paguyuban has a principle logical requires logistics, then it is often held a meal together with members of the community of semut ireng. To become a members of this community does not require certain difficult conditions. But only by participating in allactivities by undergoing the provisions that have been made in the community of semut ireng. The organization in addition to shaping the character of its members also gives a positive impact for all villagers Satriyan especially in rt $03 \mathrm{rw}$ 01, due to the activities conducted by the organization of the community of semut ireng become more advanced than before.

Keyword: The Formatin of Youth Characters

\section{PENDAHULUAN}

Organisasi merupakan suatu kesatuan yang terbentuk karena penggabungan dari beberapa orang dan sebagainya dalam suatu perkumpulan yang mempunyai tujuan tertentu. Kelompok kerja sama antara orang - orang yang diadakan untuk mencapai tujuan bersama. Tim penyusun, kamus bahasa Indonesia Eko Hadi Wiyono, 2007:440. Jadi artinya jika hanya ada seseorang atau dua orang ataupun lebih dan tidak memliki tujuan yang sama tidak dapat dikatakan sebuah organisasi. Organisasi seperti paguyuban pemuda tidak dapat terlepas dari masyarakat desa. Karena disetiap pemikiran dan jiwa masyarakat desa pasti memiliki rasa persatuan dan kesatuan. Dan jiwa gotong royong untuk melakukan berbagai hal di desa 
tersebut. Dengan adanya organisasi pemuda sebagai sarana untuk melakukan interaksi sosial mereka lebih mudah untuk mencapai apa yang mereka inginkan. Meskipun organisasi pemuda masih dalam bentuk sederhana namun sudah memiliki ciri - ciri organisasi yaitu 1. Adanya orang - orang dalam arti lebih dari satu orang 2 . Adanya kerjasama 3. Adanya tujuan.(Prof. DR. H. Abdurrahmat Fathoni, M.Si,2011).Paguyuban sendiri memiliki arti kelompok sosial yang anggotanya memiliki keterkaitan yang alamiah, suci dan murni.(Haryanto \& Nugrohadi:2011).

Dalam memecahkan masalah generasi muda diperlukan suatu wadah untuk membina dan mengarahkan generasi muda tersebut. Pelaksanaan pembinaan tersebut merupakan tugas dan kewajiban pengurus pelaksana baik dari tingkat pusat maupun daerah yang sesuai dengan bidangnya, yang diterjemahkan ke tengah masyarakat terutama dalam pemberian bantuan dan bimbingan yaitu dengan membentuk suatu organisasi yang nantinya akan menjadi wadah pernbinaan generasi muda tersebut khususnya di pedesaan. Pada dasarnya keberadaan organisasi-organisasi pemuda tersebut dimaksudkan untuk menjadi wadah penempatan diri para pemuda dalam rangka persiapan memasuki kehidupan yang sebenar-benaraya di tengah tengah masyarakat, dan juga sebagai wadah komunikasi dan pemersatu generasi muda. Selain itu organisasi pemuda juga dapat membentuk karakter yang bagus untuk para pemudanya, bahkan bisa merubah karakter buruk yang dimiliki pemuda menjadi karakter baik. Semua itu karena kebiasaan yang dilakukan dari berbagai kegiatan yang diadakan oleh organisasi pemuda tersebut.

Paguyuban pemuda merupakan salah satu organisasi pemuda yang tidak asing lagi karena merupakan wadah yang telah memiliki misi untuk membina generasi muda khususnya di pedesaan. Adapun visi paguyuban pemuda yaitu sebagai wadah pembinaan dan pengembangan kreativitas generasi muda yang berkelanjutan untuk menjalin persaudaraan dan rasa kebersamaan menjadi mitra organisasi lembaga, baik kepemudaan ataupun pemerintah dalam pengembangan kreativitas. Kemampuan dibidang kesejahteraan sosial baik untuk masyarakat dilingkungan sekitar ataupun di wilayah lain. Dalam bidang kesejahteraan sosial, paguyuban pemuda sebagai organisasi sosial masyarakat di pedesaan akan ditingkatkan fungsi dan perannya agar dapat menghimpun menggerakkan dan menyalurkan peran serta generasi muda dalam pembangunan. Selain mewujudkan kesejahteraan sosial di desa, paguyuban ini berfungsi mengembangkan potensi kreatifitas generasi muda agar secara terarah 
generasi muda di pedesaan membina dirinya sebagai pendukung pembangunan pedesaan. Serta ikut berperan aktif dalam kegiatan masyarakat pedesaan.

Paguyuban pemuda yang berada di desa Satriyan Rt 03 ini bernama Paguyuban Semut Ireng. Nama paguyuban ini diambil dari salah satu filosofi mengenai hewan semut. Mereka menganggap bahwa hewan semut dapat bekerja sama atau secara gotong royong untuk mendapatkan sesuatu yang diinginkan dan menyelesaikan hal apapun dengan mudah. Paguyuban semut ireng ini digunakan sebagai sarana meraih hasil dan tujuan warga masyarakat desa Satriyan Rt 03 yang sebelumnya tidak dapat diraih oleh individu atau secara sendiri-sendiri.dan memiliki tujuan bersama agar para pemuda di Satriyan memiliki karakter yang baik. Organisasi ini merupakan unit terkoordinasi yang terdiri dari setidaknya dua orang, yang berfungsi mencapai suatu tujuan tertentu. Dengan adanya organisasi paguyuban ini diharapkan pemuda pemudi serta warga masyarakat bisa mencapai tujuan dan memberikan perubahan yang lebih baik untuk daerah setempatnya walaupun masih dalam lingkup yang dibilang masih kecil. Karena jika tidak ada organisasi yang terkoordinir tidak akan dapat mecapai suatu tujuan besar warga masyarakat. Walaupun ada perkumpulan pemuda jika tidak terkoordinir juga tidak akan menghasilkan suatu capaian tertentu, karena tidak ada yang namanya aturan tertentu tujuan bersama. Tujuan yang sebenarnya dari paguyuban semut ireng adalah membentuk karakter pemuda, agar memiliki jiwa sosial yang berwujud kegiatan yang positif dan belajar usaha untuk menghasilkan uang untuk kas desa. Diharapkan paguyuban semut ireng ini mampu membantu perekonomian atau masalah keuangan yang dibutuhkan desa, seperti pemenuhan kebutuhan desa, atau acara desa seperti bersih desa, acara syukuran desa, ataupun acara-acara dalam memperingati Hari Kemerdekaan. Dengan adanya kegiatan-kegiatan positif yang menghasilkan seperti mencari botol bekas untuk dijual kembali atau didaur ulang dapat melatih ataupun menumbuhkan rasa peduli terhadap lingkungan. Tentu saja seiring berjalannya waktu juga akan menumbuhkan rasa solidaritas yang kental khas pedesaan. Hal ini juga akan mengurangi perlakuan-perlakuan negative yang dilakukan para pemuda.

Remaja merupakan generasi yang akan mewarisi Negara Indonesia pada masa yang akan datang. Tidak dipungkiri lagi remaja menjadi pilar bangsa. Karena para remaja dan pemuda yang akan tinggal di suatu Negara setelah kaum tua meninggalkan dunia. Berbagai harapan diletakkan agar mereka berupaya menjadi 
individu yang berguna serta mampu menyumbang ke arah kesejahteraan Negara secara keseluruhan. Remaja dapat menjadi indikasi kesejahteraan ataupun pendidikan di suatu Negara di mana ia tinggal. Jika pendidikan rata-rata remaja disuatu Negara berada di rentan SMA kebawah, maka dapat dikatakan bahwa Negara tersebut Negara berkembang. Menurut Hurlock,1989 remaja adalah mereka yang berada pada usia 12-18 tahun (F. J. Monks ,2000) memberi batasan usia remaja adalah 12-21 tahun. Menurut Stanley hall (dalam Santrock, 2007) usia remaja berada pada rentang 12-23 tahun. Berdasarkan batasan - batasan yang diberikan para ahli, bahwa mulainya masa remaja relative sama, tetapi berakhirnya masa remaja sangat bervariasi. Pada umumnya para remaja memiliki sifat yang masih labil, mudah penasaran, dan mencoba hal-hal baru, yang mereka anggap tren jaman sekarang. Maka dari itu para remaja atau pemuda pemudi desa Satriyan Rt 03 sangat disarankan untuk ikut berorganisasi di paguyuban semut ireng ini, sebab dengan adanya organisasi yang menampung remaja atau pemuda pemudi akan meminimalisir atau bahkan menghilangkan kebiasaan buruk seperti tren negative yang acapkali membuat kita miris. Organisasi ini tentunya akan mengarahkan pada kegiatan-kegiatan positif yang akan menumbuhkan jiwa solidaritas dan juga rasa tanggungjawab.

Perekrutan anggota organisasi paguyuban semut ireng sangat mudah yaitu dengan ikut melaksanakan segala kegiatan yang diadakan dan mentaati peraturan yang telah dibuat. Tidak ada persyaratan yang lain yang memberatkan calon anggota baru, karena pada dasarnya organisasi semut ireng didirikan untuk pembentukan karakter yang baik untuk warga desa Satriyan khususnya untuk para pemudanya. Sehingga tidak diperlukan persyaratan yang memberatkan para anggota baru yang ingin bergabung. Dalam organisasi ini akan diajarkan mengenai saling menghormati, toleransi, dan saling membantu dalam hal kebaikan, dan yang paling utama adalah menjadikan lingkungan Satriyan Rt 03 agar lebih maju lagi. Pada hakekatnya paguyuban semut ireng ini adalah wadah pembinaan dan pengembangan generasi muda menjadi generasi muda yang aktif dan positif. Organisasi ini mengemban misi tulus, ikhlas dan penuh rasa manusiawi dalam upaya mengatasi segala bentuk permasalahan generasi muda.

Dalam penelitian ini difokuskan untuk mengkaji peran paguyuban semut ireng yang menjadi wadah bagi para remaja untuk mengapresiasikan berbagai 
kegiatan sosial di daerah desa Satriyan. Untuk pembahasan yang akan dicantumkan yang pertama gambaran organisasi paguyuban semut ireng, yang kedua struktur dari organisasi paguyuban semut ireng, yang ketiga bentuk - bentuk kegiatan dalam pembentukan jiwa para pemuda dan perantara untuk mensejahterakan masyarakatnya, dan yang terakhir adalah peran - peran paguyuban dalam membentuk karakter baik para pemuda desa Satriyan.

Penelitian ini bertujuan untuk mendeskripsikan struktur organisasi Paguyuban Semut Ireng dan kegiatan - kegiatan apa saja yang dilakukan dalam mengembangkan keaktifan para remaja dan melakukan sesuatu hal utuk desa Satriyan. Selanjutnya hasil penelitian ini dapat memberi manfaat baik dalam kegiatan praktisi maupun akademik. Dalam kegiatan praktisi diharapkan dapat menjadi input bagi pengambil kebijaksanaan. Dari segi akademik diharapkan dapat memberi kontribusi ilmiah dalam rangka pemngembangan ilmu pengetahuan mengenai fenomena sosial.

Konsep - konsep yang digunakan dalam tulisan meliputi pengertian peranan menurut Soekanto (2002:27), peran adalah aspek dinamis dari kedudukan (status). Apabila seorang melaksanakan hal dan kewajibanya sesuai dengan kedudukannya, maka ia menjalankan suatu peran. Menurut kamus bahasa Indonesia Eko Hadi Wiyono, 2007:440. Peran adalah perangkat tingkah yang diharapkan dimiliki oleh orang yang berkedudukan dalam masyarakat.

\section{TINJAUAN PUSTAKA}

\section{Pengertian Paguyuban}

Menurut Haryanto \& Nugrohadi:2011 pengertian paguyuban adalah kelompok sosial yang anggotanya memiliki keterkaitan yang alamiah, suci dan murni. Seperti yang dikatakan oleh Udin wakil ketua paguyuban semut ireng Paguyuban memiliki anggota yang memiliki rasa yang sangat dekat. Sering bertemu dan memiliki rasa saling membutuhkan. Yang artinya sejumlah orang yang sering saling bertatap muka dan memiliki rasa saling membutuhkan dalam mencapai tujuan tertentu.

paguyuban menurut saya anggota yang memiliki keterkaitan sangat dekat dan merasa saling membutuhkan satu sama lain. Tambahan dari Daru Andri selaku anggota paguyuban semut ireng. Artinya semua anggota dari 
paguyuban memiliki keterkaitan dalam hal sosial atau dalam segala hal yang menyangkut kepentingan desa.

\section{Pengertian Remaja}

Menurut (Hurlock,1989) Pengertian remaja merupakan generasi yang akan mewarisi Negara Indonesia pada masa yang akan datang. Berbagai harapan diletakkan agar mereka berupaya menjadi individu yang berguna serta mampu menyumbang kea rah kesejahteraan Negara secara keseluruhan. Menurut (Hurlock,1989) remaja adalah mereka yang berada pada usia 12-18 tahun, monks, dkk (2000) memberi batasan usia remaja adalah 12-21 tahun. Menurut Stanley hall (dalam Santrock, 2007) usia remaja berada pada rentang 12-23 tahun. Berdasarkan batasan - batasan yang diberikan para ahli, bahwa mulainya masa remaja relative sama, tetapi berakhirnya masa iremaja sangat bervariasi.

\section{Pembentukan Karakter}

Pembentukan karakter para anggota paguyuban semut ireng ini dengan cara mengajaknya ikut serta dalam pelaksanaan kegiatan yang diadakan. Tidak hanya sekedar ikut mempersiapkan hal - hal yang sudah ada, namun juga dituntut untuk berpendapat atau memberikan ide untuk sebuah rencana kegiatan. Setelah semua mengemukakan pendapat masing - masing, selanjutnya akan mengadakan musyawarah mufakat. Proses tersebut akan mengajarkan semua orang berhak berpendapat dan tidak menganggap pendapatnya yang paling benar. Dalam menjalankan tugas dalam kegiatan menjadi tanggung jawab bersama, namun walaupun begitu tugas dibagi rata dengan semua panitia kegiatan sesuai keahlian masing - masing. Dengan begitu anggota paguyuban semut ireng tahu akan tanggung jawab yang ditanggungnya. Ketika ada kesalahan atau kegagalan dalam menyelesaikan tugas dalam kegiatan para anggota tidak diperkenankan menyalahkan satu orang yang sebagai penanggung jawab. Karena semua dianggap masih belajar, maka kesalahan akan ditanggung dan dibenarkan bersama - sama. Dan para anggota diperkenalkan dengan prinsip logika membutuhkan logistik, yang artinya sebelum berfikir untuk berbuat sesuatu, lebih baik makan terlebih dahulu, karena untuk berbuat memerlukan pemikiran dan energi agar tidak kesulitan dalam berfikir untuk berbuat sesuatu. Selaras dengan kebiasaan dari organisasi paguyuban semut ireng yang selalu mengadakan tasyakuran setelah mengadakan suatu keperluan yang 
berjalan dengan lancar, hal ini juga menjaga rasa kesolidaritasan dari masing masing anggota paguyuban semut ireng.

\section{METODE}

Metode penelitian yaitu cara atau jalan yang dilakukan secara berurutan dalam suatu penelitian, yaitu dengan alat apa dan prosedur bagaimana suatu penelitian Penelitian ini merupakan penelitian Kualitatif Deskriptif yaitu penelitian yang bertujuan menjawab, memecahkan, menggambarkan gejala sosial yang terjadi pada saat sekarang. Seperti yang dikatakan oleh Winarni Surakhmad (1983:93) yaitu : Penelitian deskriptif tertuju pada pemecahan masalah yang ada pada masa sekarang yang mencakup teknik deskriptif, diantaranya adalah penyelidikan dengan tehnik survei, interview, observasi atau dengan teknik test. Jadi dengan metode deskriptif ini penulis akan menempuh langkah-langkah melakukan representative objek tentang gejala-gejala yang dapat dalam masalah - masalah yang diteliti antara penyelidikan dengan tehnik survei, interview, observasi sehingga dengan metode deskriptif ini dapatlah diketahui gambaran umum yang terjadi pada masa sekarang.

Teknik pengumpulan data berisikan uraian tentang teknik alat ukur instrumen. Penelitian yang digunakan sesuai dengan tujuan penilitian dan jenis data yang diinginkan. Kualitas data ditentukan oleh alat pengumpul data. Dalam penulisan ini maka peneliti menggunakan alat pengumpul data untuk memperoleh data-data di lapangan, seperti pengumpulan data dengan cara ini penulis lakukan dengan mengadakan pengamatan langsung ke lokasi penelitian guna melihat secara langsung mengenai situasi dan keadaan yang sebenarnya sebagai pelengkap dan perbandingan dengan keterangan yang lebih lengkap dari teori-teori yang ada dalam bahan pustaka. Wawancara adalah cara untuk mendapatkan informasi dengan bertanya pada responden dan sebelumnya sudah dipersiapkan, sehingga akan diperoleh data-data atau keterangan yang lebih lengkap. Disini saya telah mewawancarai tiga anggota paguyuban semut ireng yaitu anggota organisasi paguyuban semut ireng Daru Andri, Mujidi selaku ketua anggota semut ireng, dan Udin selaku anggota semut ireng. Pengumpulan dokumen adalah cara untuk memperoleh data dari suatu lembaga yang dipersiapkan dalam hal ini adalah data yang ada di desa. Disini saya mengambil foto saat paguyuban semut ireng mengadakan kegiatan. 


\section{HASIL PENELITIAN DAN PEMBAHASAN}

\section{Gambaran Paguyuban Semut Ireng}

Paguyuban Semut Ireng ini dibentuk pada tahun 2016 tepatnya pada bulan Agustus. Awal mula berdirinya Paguyuban Semut Ireng ini adalah ketika masyarakat desa Satriyan yang mengadakan perayaan HUT kemerdekaan RI, namun belum ada yang ingin menjadi relawan sebagai panitia kegiatan. Dan Ketua Rt 03 berniat untuk mengumpulkan seluruh remaja baik pemuda pemudi wilayah Rt 03 nuntuk bertujuan membentuk suatu organisasi dan agar terbentuknya panitia penyelenggaraan kegiatan yang diadakan. Dalam jangka waktu kurang lebih 4 kali pertemuan organisasi ini mulai terbentuk. Dan pada awalnya mereka belum terfikirkan nama untuk organisasi mereka. Dalam penelitian ini mengatakan bahwa para remaja yang selaku anggota mulai peduli dengan lingkungan dan organisasi yang telah dibentuk. Mereka memfikirkan nama yang dapat mereka gunakan untuk organisasi mereka. Dan alhasil para anggota Paguyuban Semut Ireng mengambil dari salah satu filosofi dari hewan semut. Yang dianggap hewan semut tersebut bisa berkumpul dengan komponinya untuk mengerjakan suatu hal apapun. dengan kerukunan dan hasil gotong royongnya semut pasti bisa berhasil melakukan apapun yang mereka inginkan. Sehingga Paguyuban pemuda ini mendapatkan nama yaitu, Paguyuban Semut Ireng dalam artian mereka berharap agar mereka bisa seperti semut yang hidup dengan kebersamaan dan kesatuan akan mempermudah pekerjaan yang berat.

Setelah terbentuknya organisasi Paguyuban Semut Ireng, mereka berkomitmen untuk mengajak seluruh pemuda pemudi dilingkungan sekitar ikut serta menjadi anggotanya dan menumbuhkan jiwa sosial pada seluruh anggotanya, dan yang tidak kalah pentingb membangun jiwa patriotisme agar menjadi pribadi yang lebih baik dan berguna bagi bangsa dan Negara. Karena hanya para pemuda dan pemudilah yang akan menjadi penerus bangsa. Dengan adanya organisasi Paguyuban Semut Ireng ini akan mengatur waktu para pemuda pemudi untuk mencegah melakukan hal yang berdampak negative bagi dirinya sendiri dan orang lain.

Selain bertujuan untuk mengembangkan jiwa remaja, Paguyuban Semut Ireng juga bertujuan untuk lebih menghidupkan Desa Satriyan Khususnya di lingkungan Rt 03. Dengan adanya suatu organisasi yang terkoordinasi akan membuat lingkungan lebih aktif dalam kegiatan - kegiatan sosial didesa. Yang awalnya tidak pernah 
mengadakan kegiatan perayaan HUT RI setelah terbentuknya organisasi Paguyuban Semut Ireng warga Satriyan Rt 03 bisa mengadakan perayaan. Dan yang sebelumnya harus meminta sumbangan ke warga untuk biaya perayaan dengan adanya kegiatan kegiatan yang dilakukan Paguyuban Semut Ireng sekarang tidak perlu untuk meminta sumbangan kepada warga. Karena sebagian kegiatan dari Paguyuban Semut Ireng dapat menghasilkan dana.

Paguyuban Semut Ireng ini sudah mulai berjalan lancar dalam jangka waktu satu tahun. Dan didalam organisasi ini tentunya terkoordinir dan berstruktur. Dan selalu menanggung kesalahan dalam kebersamaan, tidak menitik beratkan kepada salah seorang yang bersangkutan dengan kesalahan tersebut.

\section{Struktur Paguyuban Semut Ireng}

Organisasi Paguyuban Semut Ireng ini juga berstruktur layaknya Organisasi besar yang lain. Sebagai suatu organisasi, Paguyuban Semut Ireng dalam menjalankan aktivitas dikelola oleh pengurus yang terdiri dari seorang ketua, wakil ketua, sekertaris I dan II, bendahara I dan II, dan penasehat. Para pengurus ini diberi tugas untuk bertanggung jawab penuh atas kepengurusan kepentingan organisasi, menjalankan tugas dan kewajibannya dalam melaksanakan kegiatan. Penjelasan dari masing - masing pengurus sebagai berikut, tugas dari seorang ketua adalah memimpin dan membimbing seluruh anggotanya untuk melakukan kegiatan dalam tugasnya masing - masing. Tugas dari wakil ketua adalah membantu kaetua jika ketua mendapatkan halangan sehingga tidak bisa mengikuti kegiatan, selain itu wakil ketua juga bertanggung jawab atas pengawasan dan pembimbingan terhadap anggota. Tugas dari sekertaris I adalah mencatat segala hal yang mengandungb ide, pokok pikiran atau kegiatan - kegiatan yang akan dilaksanakan seluruh anggota. Tugas sekertaris II membantu pencatatan sekertaris I. dan tugas dari bendahara I adalah mencatat laporan keuangan hasil dari kegiatan Paguyuban Semut Ireng yang menghasilkan dana. Sedangkan tugas dari Bendahara II adalah mencatat khusus uang kas dari anggota Paguyuban Semut Ireng pribadi. Karena memang ada perbedaan uang kas dari kegiatan dan uang kas dari diri pribadi anggota Semut Ireng. Dan yang terakhir adalah tugas penasehat yaitu menilai hal - hal yang dilakukan anggota Semut Ireng dan memberikan saran atau nasehat jika ada hal yang dinilai kurang baik untuk dilakukan. 
Menurut penasehat Paguyuban Semut Ireng harus memiliki kekayaan atau uang kas yang lebih, maka dari itu diadakan kegiatan yang dapat menghasilkan dana. Jika hanya mengandalkan iuran dari anggota tidak akan cukup untuk mengadakan kegiatan atau agenda untuk masyarakat sekitar, seperti perayaan HUT RI. Selain untuk mendapatkan ekonomi yang lebih, kegiatan ini tentunya juga dapat membentuk karakter para anggota untuk berpikir kritis untuk berbuat sesuatu hal dan membiasakan para anggota untuk selalu berusaha dalam mencapai sebuah tujuan.

\section{Bentuk Kegiatan dalam Membentuk Jiwa para Pemuda dan Mensejahterakan Masyarakat}

Tujuan dari Paguyuban Semut Ireng adalah membentuk karakter pemuda agar lebih baik lagi dan mensejahterakan masyarakatnya.

Kata Daru Andry salah satu anggota Paguyuban Semut Ireng adalah

Paguyuban Semut Ireng wadah untuk menyatukan remaja remaja di desa Satriyan Rt 03 khususnya, supaya mereka dapat berkumpul, mengingat karena dari kesibukan diri masing masing pemuda, mereka jarang bertatap muka.

Dengan tujuan tersebut Paguyuban Semut Ireng mengadakan kegiatan kegiatan sebagai berikut:

1. Kegiatan bakti sosial yang bertujuan untuk membentuk jiwa sosial bagi para remaja anggota paguyuban. Menurut penelitian ini setiap dua bulan sekali mereka melakukan observasi dalam hal pemilihan rumah warga Rt 03 yang sudah tidak layak huni. Dalam artian rumah yang masih menggunakan gedek, atau rumah yang sudah rusak dan juga membahayakan orang yang menempatinya. Menurut dari ketua Paguyuban Semut Ireng, mereka sudah berhasil merenovasi dua rumah dalam satu tahun. Biaya yang digunakan dari kegiatan Paguyuban Semut Ireng selain bakti sosial yang menghasilkan dana, dan iuran dari para anggota. Tanpa melibatkan warga masyarakat yang lain. Hal ini ditujukan agar para anggota Paguyuban memilki rasa saling membantu dan warga masyarakat juga merasakan dampak positifnya.

2. Kegiatan mengumpulkan barang bekas dari warga untuk dibeli dan dijual kembali. Menurut dari pengamatan saya kegiatan ini termasuk simbiosis mutualisme. Untuk para anggota paguyuban memiliki keuntungan 
medapatkan pemasukan untuk kas, dan pengalaman suatu usaha, karena tidak semua bisa melakukan hal tersebut deengan alasan tertentu. Untuk warga masyarakat memiliki keuntungan mendapatkan penghasilan dan rumah menjadi bersih tidak ada barang bekas yang tidak berguna lagi, dan tidak perlu mencari orang yang mau membeli barang bekasnya. Pemasukan Paguyuban Semut Ireng ini akan digunakan untuk melakukan bakti sosial dan untuk agenda yang diadakan didesanya tersebut. Dana yang dihasilkan dari kegiatan ini dibukukan dan dikelola oleh bendahara paguyuban semut ireng dengan rencana yang sudah disusun oleh sema anggota paguyuban.

3. Kegiatan arisan untuk perkumpulan rutin yang dilakukan oleh anggota Paguyuban Semut Ireng. Kegiatan ini dilakukan dalam kurun waktu dua minggu sekali. Kegiatan ini juga untuk mengumpulkan uang kas yang diambil dari uang arisan yang sudah mbetok atau sudah kembali uangnya. Kegiatan arisan ini sudah disetujui semua anggota, jadi tidak ada unsur keterpaksaan. Jika ada yang berkeberatan anggota boleh tidak mengikuti kegiatan ini. Namun sesuai dengan pengamatan semua anggota tidak keberatan jika sebagian dari uang mereka diambil untuk kas dan digunakan untuk kegiatan yang positif di desa mereka.

4. Paguyuban Semut Ireng juga mengadakan agenda rutinan setiap satu tahun sekali yaitu perayaan HUT kemerdekaan RI. para anggota selalu mengadakan lomba - lomba untuk anak - anak, remaja bahkan ibu - ibu. Dana untuk mengadakan lomba diambil dari kas anggota paguyuban baik dari iuran pribadi maupun dari hasil kegiatan paguyuban Semut Ireng. Selain mengadakan lomba juga membuat gapura khusus untuk Rt 03. Untuk memberi kesan meriah di desa Satriyan.

5. Dan yang terakhir kegiatan yang tidak selalu dilakukan. Yaitu membuat lahan parkir, karena tempat desa Satriyan dekat dengan kantor kabupaten yang sering mengadakan agenda besar, Paguyuban Semut Ireng mengambil peluang tersebut untuk membuat lahan parkir. Dalam pembentukan lahan parkir juga selalu dibentuk panitia agar semua terbiasa akan tanggung jawab masing - masing anggota. Hasil dari membuka lahan parkir dimasukkan kedalam kas Paguyuban Semut Ireng. 
Waktu yang selalu digunakan untuk kegiatan ini ketika malam tahun baru. Sudah berjalan dua tahun berturut - turut paguyuban semut ireng ini membuka lahan parkir di tempat yang dekat dengan kantor kabupaten. Namun tidak dipungkiri sebagian uang dari hasil membuka lahan parkir tidak hanya digunakan untuk kegiatan positif desa Satriyan, namun juga untuk berlibur para anggota paguyuban semut ireng untuk sejenak menghibur para anggota. Selain semua yang telah disebutkan diatas, anggota paguyuban semut ireng berencana untuk mengadakan kegiatan yang berbasis ekonomi. Kegiatan tersebut adalah membudidayakan jamur tiram. Karena anggota paguyuban semut ireng sudah banyak membantu kelancaran dalam hal apapun di desa, maka tidak heran jika ada donator yang dengan sukarela memberikan modal awal untuk memulia usaha jamur tiram tersebut. Jadi anggota paguyuban semut ireng tinggal memikirkan bagaimana cara membudi daya jamur tiram tersebut dengan baik, agar menghasilkan panenan yang memuaskan.

intinya kegiatan Paguyuban Semut Ireng untuk membangun jiwa sosial para anggotanya terhadap lingkungan sekitar tempat tinggal anggota tersebut. Contohnya dimintai tolong untuk membantu renovasi rumahnya Mak Yem, membuatkan dapur mbah Suwati yang kurang mampu di desa Satriyan. Membangun jembatan didekat rumahnya Hj. Salamun. Dan tidak hanya dari segi sosial anggota juga melakukan kegiatan yang mengambil keuntungan dari sisi ekonomi, contoh kegiatanya adalah bank sampah. Tambahan dari Daru Andry.

Artinya kegiatan yang dilakukan Paguyuban Semut Ireng yang membentuk karakter jiwa pemuda juga berdampak positif bagi sebagian warga desa yang bersangkutan. Hal ini menunjukan bahwa kegiatan yang dilakukan oleh organisasi tidak hanya itu itu saja.

sebenarnya dari setiap kegiatan yang dilakukan Semut Ireng memberi dampak positif untuk anggota dan warga sekitar. Tetapi menurut saya hal yang paling dapat membentuk karakter anggota serta bermanfaat bagi warga sekitar adalah ikut membantu ketika ada tetangga yang mengalami kesusahan, seperti halnya kematian. Karena disetiap peristiwa itu selalu dibutuhkan tenaga muda. Penjelasan dari Daru Andri 


\section{Peran - peran Paguyuban Semut Ireng dalam Membentuk Karakter Baik}

\section{kepada Pemuda}

1. Peran paguyuban semut ireng dalam membentuk karakter saling membantu dengan sesame, yaitu dengan cara mengajak para pemuda untuk berkegiatan seperti bakti sosial. Bakti sosial disini membantu renovasi rumah - rumah warga yang sudah tidak layak pakai. Dengan adanya kegiatan tersebut para pemuda juga akan merasakan bagaimana cara membantu orang lain yang membutuhkan.

2. Peran paguyuban semut ireng dalam membentuk karakter pemuda dalam hal kekompakan antar sesame dan kebersamaan adalah dengan cara mengadakan kegiatan membuka lahan parkir ketika ada agenda disekitar desa. Membuka lahan parkir yang dibentuk struktur jelas akan mengajarkan dan membiasakan para pemuda untuk menjalin kekompakan dalam menyelesaikan suatu kegiatan atau permasalahn yang dihadapi. Selain membuka lahan parkir diadakannya arisan pemuda, guna untuk perkumpulan setiap dua minggu sekali. Tujuannya untuk meskipun belum ada kegiatan lain, semua anggota tetap bisa berkumpul bersama. Kegiatan - kegiatan tersebut juga menghasilkan uang yang dapat dimasukkan dalam kas paguyuban semut ireng. Dan dari dana tersebut organisasi paguyuban semut ireng bidsa mengadakan berbagai kegiatan di masyarakat.

3. Peran paguyuban dalam membentuk karakter pekerja keras untuk para pemuda dengan cara mengadakan usaha yang dilakukan semua anggota paguyuban semut ireng, seperti mengumpulkan barang bekas rumah tangga yang berasal dari masyarakat dan dijual kembali ke pengepul sampah daur ulang. Kegiatan ini akan mengajarkan bagaimana agar memiliki usaha sendiri dan bagaimana menjalankannya. Karena tidak semua orang bisa melakukan hal seperti tersebut.

\section{KESIMPULAN}

Paguyuban Semut Ireng ini merupakan suatu organisasi sosial masyarakat yang bergerak pada bidang sosial yang bertujuan untuk membentuk pribadi remaja 
agar lebih baik dan memajukan lingkungan sekitar dalam hal pengetahuan dan pengalaman. Nama semut ireng yang diambil dari filosofi hewan semut, yang dikenal dengan kerukunannya. Dan diinginkan untuk para remaja memiliki sikap seperti hewan filosofi tersebut. Meskipun paguyuban tersebut masih terbentuk sederhana namun sudah berstruktur. Paguyuban Semut Ireng dalam menjalankan aktivitas dikelola oleh pengurus yang terdiri dari seorang ketua, wakil ketua, sekertaris I dan II, bendahara I dan II, dan penasehat. Para pengurus ini diberi tugas untuk bertanggung jawab penuh atas kepengurusan kepentingan organisasi, menjalankan tugas dan kewajibannya dalam melaksanakan kegiatan. Dan organisasi paguyuban ini memiliki tujuan untuk dicapai bersama. Tujuan dari Paguyuban Semut Ireng adalah membentuk jiwa pemuda agar lebih baik lagi dan mensejahterakan masyarakatnya. Perantara untuk mencapai tujuan tersebut dengan mengadakan beberapa kegiatan seperti Kegiatan bakti sosial, kegiatan mengumpulkan barang bekas dari warga untuk dibeli dan dijual kembali, kegiatan arisan untuk perkumpulan rutin yang dilakukan oleh anggota Paguyuban Semut Ireng, Paguyuban Semut Ireng juga mengadakan agenda rutinan setiap satu tahun sekali yaitu perayaan HUT kemerdekaan RI, dan yang terakhir kegiatan yang tidak selalu dilakukan yaitu membuat lahan parkir.

\section{DAFTAR PUSTAKA}

Fathoni, abdurrahmant. 2006. organisasi dan manajement sumber daya manusia. Jakarta: Rineka Cipta.

WiyonoEkoHadi. 2007. KamusBahasaIndonesia. Jakarta: Palanta.

Silalahi, Uiber. 2012. Metode Penelitian Sosial. Bandung : PT.Refika Aditama.

Sugiono. 2009. Metode Penelitian Pendidikan Pendekatan Kuantitatif, Kualitatif dan Alfabeta. Bandung.

Direktorat Bina Karangtaruna. 2005. Buku Pedoman Dasar Karang Taruna. Departemen Sosial RI.

Surakhmad, Winarno. 1983. Pengantar Penelitian Ilmiah, Dasar, Metode, Teknik. Bandung: Transito

Hurlock. 1989. Anak, Perkembangan. New York: McGraw-Hill Book Company 